\title{
The Phonetic Adaptations of Russian Loanwords in Мир Фантастики (Mir Fantastiki) for Cinematography Vocabulary
}

\author{
Novita Laily Fariana Isada \\ Russian Studies, Faculty of Humanities \\ Universitas Indonesia \\ Depok, Indonesia \\ novitalailys@gmail.com
}

\author{
Nia Kurnia Sofiah \\ Russian Studies, Faculty of Humanities \\ Universitas Indonesia \\ Depok, Indonesia \\ niadee@gmail.com
}

\author{
Njaju Jenny Malik \\ Russian Studies, Faculty of Humanities \\ Universitas Indonesia \\ Depok, Indonesia \\ je_lik@yahoo.com
}

\begin{abstract}
Language contacts occur because of the interactions between language communities, which creates opportunity for the process of borrowing words between languages. This process takes place in both spoken and written registers, including the fantasy genre, whose popularity in Russia is evident in their print media and movies. Magazines specializing in fantasy genre also apply word borrowing. One of them is Mir Fantastiki, which is devoted to media reviews, including literature, movies, and TV shows. This study examines the adaptations of loanwords into the Russian language from foreign languages in the area of cinematography in Mir Fantastiki magazine using descriptiveanalytical method by Anderson and Arsenault (2005). This analysis uses the loanword theory in general by Campbell (2013), phonetic adaptations theories (Arnold, 2012; Kodzasov, 2001; Haugen, 1972; and Kortlandt, 1973), and the theory of Russian morphology focusing on nouns by Savko (2004). The phonetic adaptations retain the original sounds from the source languages and adapt the sounds to the recipient language. The results of this study indicate that the loanwords into the Russian language are phonetically adapted in three categories. The first is the fully assimilated loanwords, which borrow the phoneme of the source language in its entirety. The second is partially assimilated loanwords, which borrow the phoneme of the source language and adjust it to the recipient language. The last is unassimilated loanwords, which borrow words without phonetic substitution. These adaptations also reserve the gender of the loan nouns.
\end{abstract}

Keywords-loanwords; phonetic adaptations; Russian language; nouns; cinematography

\section{INTRODUCTION}

Language is defined as a code or sign system which is used as a communication tool and a means of expression (Shastri, 2012). In communication, language communities interact and influence one another, commonly referred to as language contacts (Matras, 2009). One common consequence of language contacts is the process of word borrowing (Thomason, 2001, p. 10 in Zenner and Kristianse, 2013, p. 2).
Since the age of the Empire, Russia has made contacts with other nations. The advent of Glasnost exposed Russia within the Western influence in all dimensions of life, including politics, economy, social issues, law and order, science and technology, education, culture, sports, and fashion (Offord and Gogolitsyna, 2005, p. 163). Mass media is a force that accelerates the growth and development of language contacts (Rosenhouse and Kowner, 2008, p. 14). These language contacts are not limited to spoken texts but also found in the form of written texts in newspapers and magazines. Badudu (1985) supports the opinion that loanwords from foreign languages are commonly found in newspapers and magazines.

Mir Fantastiki is a monthly Russian magazine that discusses books, films, games, comics, and anime about fantasy. According to Roscon Award in the World Heritage Encyclopedia, Mir Fantastiki is the biggest and most influential fantasy magazine in modern Russia. A recent survey by the World Culture Score Index in MicDaily elicited responses from 1,600 users in 30 countries all over the world and showed that fantasy genre is the most widely read genre with a total of $32 \%$ of all the respondents, including those from Russia (Loewentheil, 2013). Fantasy genre productions are commonly found in films and mostly come from the West, which then influences the life style of the Russian people, including the language they speak. Russian film industry grew by $10.9 \%$ in 2017 compared to that of previous year (Kass, 2018). Therefore, we are interested in investigating the film vocabulary used in Mir Fantastiki.

\section{LITERATURE REVIEW}

Language contact is one of the precursors of lexical change in a language, which is related to semantic change in lexical forms, with an addition of new words to reflect new concepts as well as to substitute existing words in the language with loanwords. Occasionally this leads to a total 
word formation change (Jeffers and Lehiste, 1982). The term used to describe this type lexical change is borrowing, and the result is referred to as loanword, which essentially means a word borrowed from another language and has become part of the vocabulary in the recipient language (Campbell, 2013, p. 56).

Loanwords can be classified according to the new aspects of the vocabulary in the recipient language. I. V. Arnold (2012, pp. 229-231) and Haugen (1972) classified loanwords into four categories:

1. Заимствования подразделяются на фонетические (zaimstvovaniya podrazdeliaiutsia na foneticheskie) phonetic loans, which preserve the phoneme of the source language and adapt it to that of the recipient language. This is the most common form of loanwords in the Russian language. Examples include sport - cnopm (sport) and $c l u b-\kappa л y \sigma$ (klub).

2. Кальки (kal'ki) translation-loans, loanwords in the form of literal translation from a foreign word or expression that preserves the morphological structure and form of the source word. For example, the word 'pale-face' from the English language becomes бледнолищый (blednolitsy) in the Russian language. The word бледнолицьии (blednolitsyj) consists of бледный (blednyj), meaning 'pale' and лицьо (litso), meaning 'face'.

3. Семантические (semanticheskie) semantic loans, borrowing a new meaning for a word that already exists in the recipient language. For example, words such as brigade and pioneer already existed in the English language before the penetration of the Soviet Union, but the two words were given new meanings such as labor union and members of a pioneer organization under the influence of the Russian language after the October period.

4. Заимствования словообразовательньх элементов (zaimstvovaniya slovoobrazovatel'nyh elementov) morphemic loans, borrowing morphemes from a foreign language to be used in the recipient language as components in word formation. For example, suffixes in the Greek language such as -ist, -ism, and -isk are commonly used in other languages. The English word 'pacifist' has the same meaning as the Russian word naųuфucm (patsifist).

The focus of this research is loanword adaptations through phonetic loans. Haugen (1972) divides phonetic loans into three, namely unassimilated loanwords (borrowing based on the written form without considering the pronunciation) partially assimilated loanwords (the pronunciation of these loanwords are adapted to the recipient language) and fully assimilated loanwords (those preserving the pronunciation in the source language).

In the Russian language, loanwords have specific characteristics. According to Rakhmanova and Suzdaltseva (1997), there are several phonetic characteristics of loanwords, such as the prefix a- as in армия (armiya) 'troops'-Russian words do not have initial a-, Зияние (ziyanie), two or more adjacent vocals in one word, such as aym (aut) 'out', дуэm (duet) 'duet', and a combination of 23 (gz), кг (kg), кд (kd), кз (kz); бю (biu), вю (viu), кю (kiu), мю (miu), пю (piu) such as зигзаг (zigzag) 'zigzag', дебют (debiut) 'debut'.

Kortland (1973, pp. 75-79) discusses the phonetic transcription rules in the Russian language, which include (1) stressed vocal phonemes are written as /i/, /e/, /a/, /o/, /u/, while unstressed vocal phonemes are written as $/ l /, / \alpha /, / u /$, (2) final occlusives and fricatives are silent such as npym, пруд [prut], (3) final velars are hard such as cmux [sंtix], (4) labials and velars are hard before any consonant such as книга [kinig $\alpha$ ], and (5) dentals are always hard before phonemes $/ r /$ and $/ r^{\prime} /$ and $[\mathrm{r}$ ] is hard before dentals or palatals, but $[\mathrm{r}]$ is not neutralized before other consonants.

Every language has its own characteristics, including Russian, English and French. In the English language, the phoneme $[\mathrm{r}]$ is pronounced by curling the tip of the tongue to the palate so that the sound is not very clear (Ogden, 2009 , p. 14), while in the Russian language the consonant $[\mathrm{r}]$ is produced by trill so that the sound produced is clear (Gordon, 2012, p. 21). In the English language there is th [ $\theta]$ phoneme, which does not exist in the Russian language (Kosdzasov, 200, p. 369). The French language is known to have nasal sounds, for example in the vocal phoneme / $\tilde{a} /$

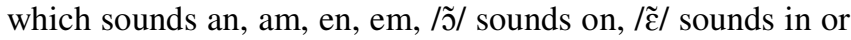
$\mathrm{im}$, and $/ \tilde{\mathfrak{e}} /$ sounds un (Price, 2005, pp. 70-73). In the French language, nouns have gender types as in the Russian language. Nouns in the Russian language are divided into three types, мужской род (mužkoj rod) 'masculine', which is comonly shown as zero morpheme [ø], женский род (ženskij rod) 'feminine', which commonly have suffixes -a and -я (-ja), and средний род (srednij rod) 'neutral', which are commonly marked with suffixes $-\mathrm{o}$ and $-\mathrm{e}$ (je) (Savko, 2004, p. 180). This kind of categorization also occurs in the French language but not in the English language.

\section{METHOD}

This research employed descriptive-analytical method. Data was collected, described and subsequently analyzed using the theory (Anderson and Arsenault, 2005, p. 105). The data comprised five loanwords through phonetic loans. They were analyzed in terms of their definitions within cinematography context, etymology, and adaptation into the Russian language. Then, conclusion was drawn based on these analyses.

\section{RESULT AND DISCUSSION}

The source of data in this research is Mir Fantastiki March 2017 edition, in particular the видеодром /videodrom/ column, which is specifically devoted to film discussions. The Foreign Language Dictionary by Yegorova (2014) was also used to gather information about the etymology of the loanwords.

1. Реме́йк (remeik) 'remake' (Mirf, Mar, 46) is defined as 'the newest version of a previously 
existing film'. Based on this definition, this loanword can be categorized into cinematography vocabulary. The word реме́йк (remeik) is a loanword from the English language 'remake' (Yegorova, 2014, p. 571), which is a noun and in the Russian language it is a singular masculine noun.

$$
\begin{aligned}
& \text { Remake - /'ri:merk/ } \\
& \text { Ремейк -/r'im'ejk/ }
\end{aligned}
$$

The comparison above shows that the word ремейк (remeik) is a fully assimilated loanword because it is pronounced as in the source language. The sound /eI/ is still pronounced /ej/ in the Russian language.

2. Продюсер (prodyuser) 'producer' (Mirf, Mar, 46) is defined as 'the owner of a production house, the head or official representative of film production and has financial control over the film production, or the film director'. Based on this definition, this loanword can be categorized into cinematography vocabulary. The word nродюсер (prodyuser) is a loanword from the English language 'producer' (Yegorova, 2014, p. 534), which is a noun and becomes продюсер (prodyuser) in the Russian language and is a singular masculine noun.

$$
\begin{aligned}
& \text { Producer - /pıə'dju:sə/ } \\
& \text { Продюсер -/pradjus'เr/ }
\end{aligned}
$$

The comparison above shows that the word nродюсер (prodyuser) is a partially assimilated loanword because the sound [r], which is not clearly pronounced in the English language, is clearly pronounced in the Russian language.

3. Три́ллер (triller) 'thriller' (Mirf, Mar, 56) is defined as a thriller film or literature with a plot which creates suspense among the readers or viewers (Krysin, 2005, p. 522). This meaning allows this word to be categorized into cinematography vocabulary. The word 'thriller' is a noun in the English language and becomes три́ллер (triller) in the Russian language and is a singular masculine noun.

$$
\begin{aligned}
& \text { Thriller - /'Orilə/ } \\
& \text { Tри́ллер -/tr'il'ır/ }
\end{aligned}
$$

Based on the above comparison, this loanword can be categorized into a partially assimilated loanword because its pronunciation has been adapted to suit the recipient language. The spelling of the word actually preserves the original spelling in the source language, but since there is no th $/ \theta /$ in the Russian language, it is replaced with $t / t /$. The sound of final consonant $r$ in the English language is not clearly pronounced, but it is clearly pronounced in the Russian language following its phonetic rules.
4. Интрúza (intriga) 'intrik' (Mirf, Mar, 65) is defined as part of the plot where a conflict begins. Based on this definition, this word can be categorized into cinematography vocabulary. The word 'intrigue' originates from the French language and has a feminine gender. It then becomes uнmpúza (intriga) in the Russian language and is a singular feminine noun (Yegorova, 2014, p. 274).

$$
\begin{aligned}
& \text { Intrigue - /ع̃trig/ } \\
& \text { Интри́са - /intr'iga/ }
\end{aligned}
$$

The comparison above shows that this word is partially assimilated because the pronunciation in the source language has been adapted to that of the recipient language. The Russian language does not have the nasal sound $/ \tilde{\varepsilon} /$ in the French language, which is pronounced as in or im, so in the Russian language it is pronounced as ин /in/. A suffix -a is then added to the loanword to preserve its feminine gender in the source language.

5. Спин-офф (spin-off) 'spin-off' (Mirf, Mar, 47) is 'a television program or film involving characters that were previously in another program or film' (Longman, 2005, p. 1594). Based on this definition, this word can be categorized into cinematography vocabulary. The word 'spin-off' originates from a noun in the English language and becomes cnuн-oфp (spin-off) in the Russian language, which is a masculine noun. This word is an example of unassimilated loanword because it is taken as is from the source language.

$$
\begin{gathered}
\text { Spin-off-/'spin.pfl } \\
\text { Cпин-oф } \phi-/ \text { sp'ın-off/ }
\end{gathered}
$$

\section{V.CONCLUSION}

There are two main research findings. First, word borrowing from foreign languages can take various forms, one of which is phonetic adaptations. Based on the analysis in this research, all types of phonetic adaptations, namely fully assimilated, partially assimilated, and unassimilated, were found. Second, as for partially assimilated phonetic adaptations, there is an adaptation to the recipient language regarding the gender of the noun by adding a suffix $-\mathrm{a}$ to mark the loanword as a feminine noun.

\section{References}

Anderson, G. J., \& Arsenault, N. (2005). Fundamentals of educational research. London: Routledge Falmer.

Arnold, I. V. (2012). Leksikologija sovremennogo Anglijskogo Yazyka. Moskva: Flinta. Retrieved from http://gen.lib.rus.ec/book/index.php?md5=EB521EDE3 144B470D3B03E2847679F09

Badudu, J. S. (1985). Cakrawala bahasa Indonesia. Jakarta: PT Gramedia Pustaka Utama.

Campbell, L. (2013). Historical linguistics: an introduction. Cambridge: The MIT Press. 
Gordon, T. (2012). The educator's guide to linguistics. USA: Information Age Publishing Inc. Retrieved from http://gen.lib.rus.ec/book/index.php?md5=ED7546E6C 83C5FC28870080E0CB57E48

Haugen, E. (1972). The ecology of language. Standford: Standford University Press.

Jeffers, Robert J., \& Lehiste. (1982). Prinsip dan metode linguistik historis (Abd. Syukur Ibrahim dan Machrus Syamsudin, Trans). Surabaya: Usaha Nasional. (Original work published 1979).

Kass, Anton. (2018). Российское кино в 2017 году установило рекорд по посещаемости и сборам. Retrieved from https://vz.ru/news/2018/1/11/903094.html

Kodzasov, S.V., \& Krivnova, O.F. (2001). Obšaja Fonetika. Moskva: Rossijskij gosudarstvennij gumanitarnij universitet.

Kortlandt, F.H.H. (1973). Phonetics and phonemics of standard Russian. Retrieved from https://openaccess.leidenuniv.nl/bitstream/handle/1887/ 1839/344_003.pdf

Krysin, L.P. (2005). Slovar' inostrannyh slov dlya shkol'nikov $i$ studentov. Moskva: Lokid Press. Retrieved from http://www.alleng.ru/d/rusl/rusl63.htm

Loewentheil, Hannah. (2013, July 3). Can you guess where in the world people read the most?. Retrieved from https://mic.com/articles/52703/can-you-guess-wherein-the-world-people-read-the-most\#.ykLexmmDQ

Longman dictionary of contemporary english ( $4^{\text {th }}$ ed.). (2005). Edinburgh Gate: Pearson Education Limited.

Matras, Y. (2009). Language contact. Cambridge: Cambridge University Press.

Mir Fantastiki. (2017). Elektroniy zhurnaly $i$ knigi. Retrieved from http://100pdf.net/hobbi-iuvlechenija/mir-fantastiki/

Offord, D., \& Gogolitsyna, N. (2005). Using russian: a guide to contemporary usage. Cambridge: Cambridge University Press.

Ogden, R. (2009). An introduction to english phonetics. Edinburgh: Edinburgh University Press. Retrieved from http://gen.lib.rus.ec/book/index.php?md5=833FC08E7 A5DBCC10D67CB52631E608D

Price, G. (2005). An introduction to french pronunciation. Malden: Blackwell. Retrieved from http://www.politicalavenue.com/languageschool/Frenc h\%20Language\%20Learning\%20Pack\%202/08. Miscell aneous/An\%20Introduction\%20to\%20French\%20Pron unciation.pdf

Rakhmanova, L. I., \& Suzdaltseva, V. N. (1997). Sovremenniy russkiy yazyk. leksika. frazeologiya. morfologiya. Moskow: Moscow State University, "Chero". Retrieved from http://gen.lib.rus.ec/book/index.php?md5=D7059D3E7 136655B74686D56F9AA7076

Rosenhouse, J., \& Kowner, R. (2008). Globally speaking: Motives for adopting English vocabulary in other languages. Clevedon, UK: Multilingual Matters.
Savko, I. E. (2004). Russkij yazyk čast' odin. Minsk: Harvest OOO.

Shastri, P. D. (2012). Fundamental aspects of translation. New Delhi: PHI Learning.

World Heritage Encyclopedia. (n.d.). Russian science fiction and fantasy. Retrieved from http://worldjournals.org/articles/Russian_science_fictio n and fantasy

Yegorova, T. V. (2014). Slovar' inostrannyh slov sovremennogo russkogo yazyka. Moskva: Adelant. Retrieved from http://gen.lib.rus.ec/book/index.php?md5=F419396FFC 7C0FD67E44153C1A531443

Zenner, E., \& Kristiansen, G. (2014). New perspective on lexical borrowing onomasiological, methodological, and phraseological innovations. Berlin: Walter de Gruyter. 
